\title{
ANALISIS HUKUM PERKEMBANGAN PERLINDUNGAN VARIETAS TANAMAN DI INDONESIA
}

\author{
Riezka Eka Mayasari*, Nur Hidayani Alimuddin \\ Dosen Fakultas Hukum, Universitas Sembilanbelas November Kolaka \\ *Penulis Korespondensi: Riezka Eka Mayasari \\ Email Korespondensi: maysariesop@gmail.com
}

\begin{abstract}
Abstrak. Penelitian ini bertujuan untuk mengetahui dan menganalisis perkembangan perlindungan varietas tanaman bagi pemulia tanaman di Indonesia. Tipe penelitian yang digunakan adalah penelitian hukum normatif (legal study research) dengan menggunakan pendekatan perundang-undangan (statute approach). Bahan hukum primer sebagai objek yang digunakan dalam penelitian ini adalah UU No. 29 Tahun 2000. Hasil penelitian menunjukkan bahwa masih banyak petani yang melakukan aktifitas dalam menghadirkan varietas baru namun tidak mengajukan perolehan Hak PVT. Selain itu, terdapat lebih dari seribu perusahaan benih yang berbadan hukum, namun masih sedikit dari perusahaan tersebut melakukan aktifitas pemuliaan tanaman. Adapun perkembangan PVT berdasarkan UU No. 29 Tahun 2000 ialah terdapat 32 atau 6,81\% yang berstatus perseorangan sebagai pemegang Hak PVT, terdapat 97 atau 20,64\% yang berstatus Pemerintah, terdapat 15 atau 3,19\% yang berstatus Perguruan Tinggi, terdapat 286 atau 60,85\% yang berstatus Perusahaan Dalam Negeri, dan terdapat 40 atau 8,51\% yang berstatus Perusahaan Luar Negeri. Diharapkan peningkatan peran dari Pusat PVTPP dalam menjalankan kegiatan rutin juga memaksimalkan hubungan kerjasama bilateral dan regional. Lebih lanjut, diharapkan pula bagi setiap perusahaan perbenihan untuk memiliki divisi litbang guna meningkatkan jumlah varietas/varietas unggul baru dengan berbagai komoditi yang lebih kompetitif.
\end{abstract}

Kata Kunci:

Pemulia Tanaman; Perusahaan Perbenihan;

PVT.

Artikel dengan akses terbuka di bawah lisensi CC BY SA-4.0

\section{PENDAHULUAN}

Pertanian yang maju, efisien, dan tangguh menjadi peranan penting dalam rangka mencapai tujuan pembangunan nasional (Iis Turniasih \& Nia Kania Dewi, 2007). Selanjutnya, untuk menunjang peranan tersebut, dibutuhkan ketersediaan varietas unggul (Vina Eka Aristya \& T. Taryono, 2019). Lebih lanjut, sumber daya plasma nutfah merupakan bahan utama pemuliaan tanaman dan juga sebagai varietas tanaman unggul yang dapat mendorong pertumbuhan industri perbenihan (Dwi Afni Maileni, 2014). Olehnya itu, negara berupaya memberikan perlindungan hukum secara memadai terkait pemegang hak kepada pelaku pemuliaan/pemulia tanaman (O. K. Saidin, 2010). 
Varietas tanaman relatif baru dalam sejarah hak kebendaan immateril sebagai bagian dari Hak Kekayaan Intelektual (Yuliana Diah Warsiki Susi Irianti, 2017). Hal tersebut dikarenakan pemulia tanaman merupakan subjek yang melakukan kegiatan penelitian, pengujian, penemuan atau pengembangan untuk menghasilkan varietas tanaman unggul (Fernando Simanjuntak \& Etty Susilowati, 2013). Adapun upaya perlindungan varietas tanaman (PVT) dimulai sejak Tahun 1990-an (Naufal Hidayat, Tengku Keizeirina Devi Azwa, \& Detania Sukarja, 2019), dengan dibentuknya UndangUndang Republik Indonesia Nomor 5 Tahun 1990 tentang Konservasi Sumber Daya Alam Hayati dan Ekosistemnya (selanjutnya disebut UU No. 5 Tahun 1990), UndangUndang Republik Indonesia Nomor 12 Tahun 1992 tentang Sistem Budidaya Tanaman (selanjutnya disebut UU No. 12 Tahun 1992), dan Undang-Undang Republik Indonesia Nomor 16 Tahun 1992 tentang Karantina Hewan, Ikan, dan Tanaman (selanjutnya disebut UU No. 16 Tahun 1992), meskipun undang-undang tersebut hanya mengatur secara parsial atau tersirat tentang PVT. Selanjutnya, pembentukan UndangUndang Republik Indonesia Nomor 29 Tahun 2000 tentang Perlindungan Varietas Tanaman (selanjutnya disebut UU No. 29 Tahun 2000), merupakan konsekuensi atas keikutsertaan Indonesia sebagai negara penandatangan kesepakatan General Agreement on Tariffs and Trade dan diratifikasi berdasarkan Undang-Undang Republik Indonesia Nomor 7 Tahun 1994 tentang Pengesahan Agreement Establishing the World Trade Organization (Persetujuan Pembentukan Organisasi Perdagangan Dunia) (selanjutnya disebut UU No. 7 Tahun 1994), dimana rangkaian persetujuan tersebut memuat tentang kesepakatan Trade-Related Aspects of Intellectual Property Rights (TRIPs) (Aspek-aspek dagang yang terkait dengan Hak Atas Kekayaan Intelektual), yang salah satu kesepakatannya menyangkut PVT.

Sistem PVT sebagaimana berdasarkan Pasal 1 angka 4 UU No. 29 Tahun 2000, menjelaskan bahwa:

"Pemuliaan tanaman adalah rangkaian kegiatan penelitian dan pengujian atau kegiatan penemuan dan pengembangan suatu varietas, sesuai dengan metode baku untuk menghasilkan varietas baru dan mempertahankan kemurnian benih varietas yang dihasilkan."

Dari ketentuan di atas, PVT hanya akan diberikan kepada pemulia tanaman yang dapat membuktikan bahwa varietas yang diajukan telah memenuhi persyaratan, diantaranya yaitu temuan baru atau belum dikenal sebelumnya (novelty), memiliki ciri dan tanda khusus (distinct), seragam (uniform) dan menunjukkan stabilitas pada lokasi dan generasi selanjutnya (stability) (Simona Bustani, 2019).

Berdasarkan uraian di atas, maka tujuan penelitian ini adalah untuk mengetahui dan menganalisis perkembangan perlindungan varietas tanaman bagi pemulia tanaman di Indonesia. Adapun manfaat dari penelitian ini ialah sebagai sosialisasi dan edukasi bagi pemulia tanaman guna memperoleh hak perlindungan varietas tanaman berupa lisensi, serta royalti atau kompensasi bernilai ekonomis.

\section{METODE PENELITIAN}

Tipe penelitian ini adalah penelitian hukum normatif (legal study research) dimana mencakup penelitian terhadap asas-asas hukum, penelitian terhadap sistematika hukum, penelitian sejarah hukum serta penelitian perbandingan hukum (Nurul Qamar 
\& Farah Syah Rezah, 2020). Penelitian ini menggunakan pendekatan perundangundangan (statute approach) yang bertujuan untuk mempelajari penerapan norma atau kaidah hukum dalam praktik hukum (Said Sampara \& La Ode Husen, 2016). Bahan hukum primer sebagai objek yang digunakan dalam penelitian ini adalah UU No. 29 Tahun 2000 tentang Perlindungan Varietas Tanaman. Teknik pengumpulan bahan hukum dalam penelitian ini adalah dengan cara menganalisis serta melakukan penelusuran yang mendalam dan sistematis terhadap peraturan perundang-undangan serta referensi-referensi hukum yang berkaitan dengan masalah yang dikaji. Lebih lanjut, analisis bahan hukum dilakukan dengan cara inventarisasi kaidah-kaidah hukum dalam peraturan perundang-undangan, melakukan kategorisasi sesuai dengan sifatnya, serta mendeskripsikan serta tujuan penelitian melalui tabel distribusi frekuensi.

\section{HASIL DAN PEMBAHASAN}

\section{A. Perlindungan Varietas Tanaman di Indonesia Berdasarkan UU No. 29 Tahun 2000}

Manfaat ekonomi merupakan salah satu wujud penghargaan, pengakuan, serta imbalan PVT atas keberhasilan pemulia tanaman, sebagaimana berdasarkan Pasal 1 angka 15 UU No. 29 Tahun 2000, menjelaskan bahwa:

"Royalti adalah kompensasi bernilai ekonomis yang diberikan kepada pemegang hak Perlindungan Varietas Tanaman dalam rangka pemberian lisensi."

Berdasarkan Pasal 8 ayat (1) UU No. 29 Tahun 2000, mengatur bahwa:

"Pemulia yang menghasilkan varietas ... berhak untuk mendapatkan imbalan yang layak dengan memperhatikan manfaat ekonomi yang dapat diperoleh dari varietas tersebut."

Adapun manfaat bagi pemulia tanaman yang memperoleh Hak PVT, antara lain yaitu (H. Hermanto et al., 2019):

1. Mendorong keterlibatan swasta dalam mengembangkan industri benih;

2. Meningkatkan daya kompetisi perusahaan industri benih;

3. Meningkatkan jumlah dan kecepatan penemuan varietas unggul baru yang kompetitif dari berbagai komoditas yang sesuai dengan wilayah spesifik;

4. Mempercepat proses penemuan varietas unggul baru oleh pihak swasta/ masyarakat sehingga tidak lagi bergantung pada pemerintah;

5. Memanfaatkan dana masyarakat dalam pengembangan industri perbenihan;

6. Meningkatkan lapangan kerja bagi masyarakat;

7. Menyediakan benih unggul baru bagi petani dalam jumlah dan jenis yang dibutuhkan, sekaligus meningkatkan pendapatan dan taraf hidup petani;

8. Meningkatkan produktivitas dan daya saing komoditas pertanian nasional dan dengan sendirinya akan meningkatkan keunggulan kompetitif bangsa;

9. Meningkatkan pendidikan dan penelitian yang terkait dengan proses pemuliaan dan pelestarian sumber daya hayati, sekaligus mengembangkan ilmu pengetahuan dan teknologi;

10. Meningkatkan gairah para pemulia dalam mengembangkan penelitian pemuliaan untuk meningkatkan kesejahteraan mereka. 
Selanjutnya, untuk memperoleh manfaat sebagaimana dimaksudkan ketentuan di atas, pemulia tanaman harus mengetahui kategori varietas, sebagaimana berdasarkan Pasal 2 ayat (1) UU No. 29 Tahun 2000, mengatur bahwa "varietas yang dapat diberi PVT meliputi varietas dari jenis spesies tanaman yang baru, unik, seragam, stabil, dan diberi nama".

Adapun keterlibatan Pemerintah dalam memberikan perlindungan hukum atas Hak PVT bagi pemulia tanaman di Indonesia terdiri dari beberapa ketentuan, diantaranya berdasarkan Pasal 2 Peraturan Menteri Pertanian Republik Indonesia Nomor 121/PERMENTAN/OT.140/11/2013 tentang Syarat dan Tata Cara Permohonan dan Pemberian Hak Perlindungan Varietas Tanaman (selanjutnya disebut Permentan No. 121/Permentan/OT.140/11/2013) mengatur bahwa Peraturan ini dimaksudkan sebagai dasar hukum dalam pelayanan pemberian Hak PVT, dengan tujuan untuk:

a. melindungi hasil pemuliaan jenis tanaman atau spesies tanaman yang baru, unik, seragam, dan stabil;

b. melindungi pemulia tanaman dalam menghasilkan varietas tanaman; dan

c. memberikan kepastian perolehan Hak PVT.

Berdasarkan Pasal 42 ayat (1) UU No. 29 Tahun 2000, mengatur bahwa "pemegang Hak PVT berhak memberi lisensi kepada orang atau badan hukum lain berdasarkan surat perjanjian lisensi", selanjutnya berdasarkan Pasal 43 ayat (1) UU No. 29 Tahun 2000, mengatur bahwa:

"Perjanjian lisensi harus dicatatkan pada Kantor PVT dan dimuat dalam

Daftar Umum PVT dengan membayar biaya yang besarnya ditetapkan oleh Menteri."

Dari ketentuan di atas, maka pemulia tanaman mesti memahami serangkaian prosedur guna menikmati manfaat ekonomi dan hak-hak lainnya yang dimana hak tersebut bersifat eksklusif (Emi Indah Lestari, Kholis Raisah, \& Adya Paramita Prabandari, 2019). Berdasarkan Pasal 11 Permentan No. 121/Permentan/ OT.140/11/2013, mengatur bahwa:

(1) Untuk memperoleh Hak PVT ..., pemohon wajib menyampaikan surat permohonan dengan dibubuhi materai yang cukup dan membayar biaya yang telah ditetapkan.

(2) Surat permohonan Hak PVT sebagaimana dimaksud pada ayat (1) paling kurang memuat:

a. tanggal, bulan dan tahun surat permohonan;

b. nama lengkap dan alamat pemohon;

c. nama lengkap dan kewarganegaraan pemulia serta nama ahli waris yang ditunjuk;

d. nama varietas;

e. deskripsi varietas yang mencakup asal-usul atau silsilah, ciri-ciri morfologi, dan sifat-sifat penting lainnya;

f. Gambar dan/atau foto yang disebut dalam deskripsi, yang diperlukan untuk memperjelas deskripsinya.

(3) Dalam hal permohonan tidak dilengkapi nama ahli waris sebagaimana dimaksud pada ayat (2) huruf c, permohonan harus disertai surat pernyataan alasan tidak dilengkapi nama ahli waris. 
(4) Dalam hal Hak PVT sebagaimana dimaksud pada ayat (1) diajukan oleh:

a. orang atau badan hukum selaku Konsultan PVT harus disertai surat kuasa khusus dengan mencantumkan nama dan alamat lengkap kuasa;

b. ahli waris harus disertai dokumen bukti ahli waris; atau

c. penerima lebih lanjut hak atas varietas yang bersangkutan disertai bukti penerimaan hak.

Adapun bagan prosedur permohonan Hak PVT antara lain sebagai berikut.

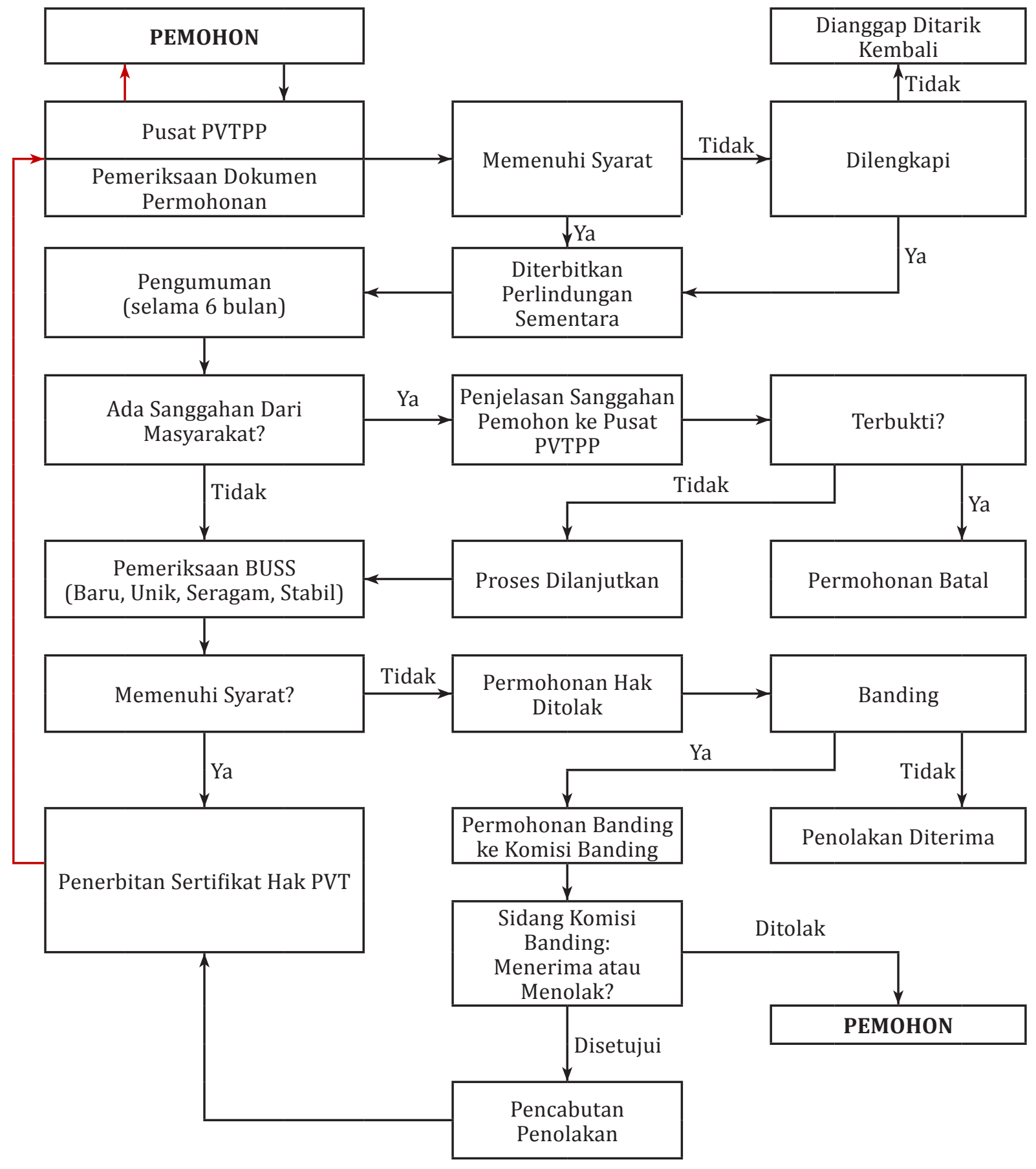


Dengan diaturnya hak-hak bagi pemulia tanaman, maka diharapkan dapat mendorong kreativitas, hingga mendatangkan investasi di bidang pemuliaan tanaman, sehingga dapat menghasilkan berbagai penemuan varietas unggul bermutu yang mendukung industri perbenihan modern (Prasetyo Hadi Purwandoko \& Moch. Najib Imanullah, 2013). Dilain sisi, PVT juga bertujuan untuk mengembangkan dan membangun industri perbenihan nasional guna mengantisipasi era globalisasi (persaingan terbuka), masalah pangan nasional, kependudukan, ketenagakerjaan dan pendapatan masyarakat secara luas, serta pemanfaatan kekayaan sumber daya hayati nasional (Roosganda Elizabeth, 2019).

Dari serangkaian uraian di atas, apabila para pemulia tanaman dapat mengimplementasikan UU No. 29 Tahun 2000, maka akan terjadi peningkatan jumlah varietas/varietas unggul baru. Hal ini disebabkan karena Indonesia sebagai negara "mega biodiversity" merupakan negara yang kaya akan keanekaragaman hayati yang dapat dimanfaatkan sebagai sumber daya genetik (Aktris Nuryanti, 2015).

\section{B. Analisis Hukum Perkembangan Perlindungan Varietas Tanaman di Indonesia}

Pada Tahun 1961, telah dilaksanakan Union Pour la Protection des Obtentions Vegetales (UPOV). Konvensi tersebut menghadirkan suatu kebijakan yang menjadi dasar atas penguasaan pasar benih. Kebijakan tersebut diwarnai oleh kepentingan perusahaan raksasa benih (H. Hermanto et al., 2019). Selanjutnya pada Tahun 1994, dilaksanakan pembentukan World Trade Organization (WTO), dimana rangkaian persetujuan tersebut memuat tentang TRIPs. Setiap anggota WTO wajib meratifikasi kesepakatan perdagangan dunia dan membuat suatu regulasi terkait perlindungan varietas tanaman yang mereka perdagangkan. Indonesia sebagai negara anggota WTO sebagaimana berdasarkan UU No. 7 Tahun 1994, lebih memilih Sui Generis tanpa harus menjadi anggota UPOV (Putu Ayu Sriasih Wesna, 2020).

PVT di Indonesia sudah dimulai sejak 1990, yakni dengan berdasarkan UU No. 5 Tahun 1990, UU No. 12 Tahun 1992, UU No. 16 Tahun 1992, dan UU No. 29 Tahun 2000. Meskipun bukan negara anggota UPOV, Indonesia dalam pembentukan regulasinya tetap merujuk pada konvensi UPOV (Hendra Djaya, 2015). Hal ini dapat ditemukan pada bagian penjelasan umum dan beberapa ketentuan, khususnya yang termuat pada pasal-pasal dalam UU No. 29 Tahun 2000, misalnya pada Pasal 19 ayat (4) UU No. 29 Tahun 2000, mengatur bahwa:

(1) apabila untuk satu varietas dengan sifat-sifat yang sama ternyata diajukan lebih dari satu permohonan Hak PVT, hanya permohonan yang telah diajukan lengkap terlebih dahulu yang dapat diterima.

(2) Permohonan Hak PVT sebagaimana dimaksud pada ayat (1) yang diajukan pada saat yang sama, maka Kantor PVT meminta dengan surat kepada pemohon tersebut untuk berundingan guna memutuskan permohonan yang mana diajukan dan menyampaikan hasil keputusan itu kepada Kantor PVT selambat-lambatnya enam bulan terhitung sejak tanggal pengiriman surat tersebut. 
(3) Apabila tidak tercapai persetujuan atau keputusan di antara pemohon Hak PVT atau tidak dimungkinkan dilakukan perundingan atau hasil perundingan tidak disampaikan kepada Kantor PVT dalam waktu yang ditentukan sebagaimana dimaksud pada ayat (2), maka permohonan Hak PVT tersebut ditolak dan Kantor PVT memberitahukan hal tersebut secara tertulis kepada pemohon Hak PVT tersebut.

(4) Apabila varietas sebagaimana dimaksud pada ayat (1) menyangkut varietas yang diajukan dengan hak prioritas, maka dianggap sebagai tanggal penerimaan adalah tanggal penerimaan permohonan Hak PVT yang pertama kali diajukan di luar negeri.

Selanjutnya, beberapa peran Pusat Perlindungan Varietas Tanaman dan Perizinan Pertanian (Pusat PVTPP) dalam mengelola perkembangan PVT, ialah melaksanakan kegiatan rutin serta kerjasama bilateral dan regional (Ira Puspita Sari Wahyuni, 2013). Adapun kegiatan rutin yang dimaksud yakni membangun dan mengembangkan sistem pelayanan PVT (infrastruktur dan sumber daya manusia), mengembangkan sistem operasional PVT, serta diseminasi sistem PVT sebagai pemicu dalam pengembangan industri benih (Hasim Ashari, Ujang Sumarwan, \& K. Kirbrandoko, 2013). Lebih lanjut, A. J. P. van Wijk (2002) menyatakan bahwa:

"Kerjasama bilateral bertujuan untuk menyediakan varietas baru bagi masyarakat, akses varietas dari luar negeri bagi para pemulia, keanekaragaman genetik, dan mendukung upaya peningkatan nilai ekspor."

Sejak tahun 2004 dimana mulai dilaksanakan pelayanan permohonan Hak PVT, dan hingga saat ini terus mengalami peningkatan permohonan Hak PVT secara akumulatif. Hingga Oktober 2019, pemulia tanaman yang telah mengajukan permohonan Hak PVT, berjumlah sebanyak 748. Adapun uraian permohonan Hak PVT, dapat dilihat pada tabel di bawah ini.

\section{Tabel 1. Jumlah Kumulatif Permohonan Hak PVT hingga Tahun 2019}

\begin{tabular}{c|l|c|c}
\hline \hline \multirow{2}{*}{ No } & \multicolumn{2}{|c|}{ Status Permohonan } & \multicolumn{2}{|c}{ Jumlah Permohonan Hak PVT } \\
\cline { 3 - 4 } & & Frekuensi & Presentase \\
\hline \hline 1 & Dalam Proses & 118 & $15,78 \%$ \\
\hline 2 & Ditolak & 27 & $3,61 \%$ \\
\hline 3 & Ditarik Kembali & 133 & $17,78 \%$ \\
\hline 4 & Diterima & 470 & $62,83 \%$ \\
\hline \hline
\end{tabular}

Sumber: H. Hermanto et al. (2019)

Dari tabel di atas menunjukkan bahwa terdapat 118 atau 15,78\% yang berstatus dalam proses berdasarkan total permohonan Hak PVT, terdapat 27 atau 3,61\% yang berstatus ditolak, terdapat 133 atau 17,78\% yang berstatus ditarik kembali, dan terdapat 470 atau 62,83\% yang berstatus diterima. Dapat dinilai bahwa berdasarkan permohonan Hak PVT hingga Tahun 2019, Pusat PVTPP telah menerbitkan 470 Sertifikat Hak PVT. 
Dilain sisi, sebagian besar pemulia tanaman mengajukan permohonan Hak PVT dengan kategori sayuran dan palawija (Sri Umi Lestari, Reza Prakoso Dwi Julianto, \& Astri Sumiati, 2017). Adapun 10 jenis tanaman yang paling banyak memiliki sertifikat Hak PVT, dapat dilihat pada tabel di bawah ini.

\section{Tabel 2. Jenis Tanaman yang Paling Banyak Memiliki Sertifikat Hak PVT} hingga Tahun 2019

\begin{tabular}{c|l|c|c}
\hline \hline \multirow{2}{*}{ No } & \multirow{2}{*}{ Jumlah Tanaman } & \multicolumn{2}{c}{ Jumlah Hak PVT } \\
\cline { 3 - 4 } & & Frekuensi & Presentase \\
\hline \hline 1 & Padi & 61 & $12,98 \%$ \\
\hline 2 & Jagung & 40 & $8,51 \%$ \\
\hline 3 & Jagung Hibrida & 37 & $7,87 \%$ \\
\hline 4 & Kacang Panjang & 34 & $7,23 \%$ \\
\hline 5 & Jagung Manis & 30 & $6,38 \%$ \\
\hline 6 & Mentimun & 30 & $6,38 \%$ \\
\hline 7 & Buncis & 17 & $3,62 \%$ \\
\hline 8 & Paria & 16 & $3,40 \%$ \\
\hline 9 & Tomat & 15 & $3,19 \%$ \\
\hline 10 & Melon & 14 & $2,97 \%$ \\
\hline 11 & Lainnya & 176 & $37,47 \%$ \\
\hline \hline
\end{tabular}

Sumber: Data Diolah dari Pusat PVTPP (2020)

Meskipun UU No. 29 Tahun 2000 telah memberikan kepastian hukum atas serangkaian manfaat ekonomis, masih banyak petani yang melakukan aktifitas dalam menghadirkan varietas baru namun tidak mengajukan perolehan Hak PVT (Moch. Najib Imanullah, 2013). Kondisi ini sangat mengkhawatirkan, dimana mungkin bagi pihak lain untuk mengajukan Hak PVT dari aktifitas para pemulia tanaman (Brian Kusuma, 2018), dan pada akhirnya para pemulia tanaman hanya dijadikan alat untuk penjualan produk unggulnya tersebut (Tito Hardiyanto \& Cecep Pardani, 2017). Adapun pemulia tanaman sebagai Pemegang Hak PVT hingga Oktober 2019, antara lain sebagai berikut.

Tabel 3. Perseorangan sebagai Pemulia Tanaman Pemegang Hak PVT hingga Tahun 2019

\begin{tabular}{c|c|c|c|c}
\hline \hline \multirow{2}{*}{ No Nama Pemegang Hak PVT } & \multicolumn{2}{|c|}{ Jumlah Hak PVT } & \multirow{2}{*}{$\begin{array}{c}\text { Presentase } \\
\text { Keseluruhan }\end{array}$} \\
\cline { 3 - 5 } & & Frekuensi & Presentase & \\
\hline \hline 1 & Sanoto Utomo & 17 & $53,13 \%$ & $3,63 \%$ \\
\hline 2 & Ir. Arifin Noor Sugiharto, M.Sc., Ph.D & 8 & $25,00 \%$ & $1,70 \%$ \\
\hline 3 & Prof. Dr. Ir. Kuswanto. M,P. & 5 & $15,63 \%$ & $1,06 \%$ \\
\hline 4 & Rudy Madiyanto & 1 & $3,12 \%$ & $0,21 \%$ \\
\hline 5 & Sigit Prastowo, S.Pt. & 1 & $3,12 \%$ & $0,21 \%$ \\
\hline \hline & Total & 32 & $\mathbf{1 0 0 , 0 0 \%}$ & $\mathbf{6 , 8 1 \%}$ \\
\hline \hline
\end{tabular}

Sumber: Data Diolah dari Pusat PVTPP (2020) 
Tabel 4. Pemerintah sebagai Pemulia Tanaman Pemegang Hak PVT hingga Tahun 2019

\begin{tabular}{|c|c|c|c|c|}
\hline \multirow{2}{*}{ No } & \multirow{2}{*}{ Nama Pemegang Hak PVT } & \multicolumn{2}{|c|}{ Jumlah Hak PVT } & \multirow{2}{*}{$\begin{array}{l}\text { Presentase } \\
\text { Keseluruhan }\end{array}$} \\
\hline & & Frekuensi & Presentase & \\
\hline 1 & $\begin{array}{l}\text { Badan Penelitian dan Pengembangan Pertanian } \\
\text { Indonesian }\end{array}$ & 47 & $48,45 \%$ & $10,00 \%$ \\
\hline 2 & Balai Besar Penelitian Tanaman Padi & 10 & $10,31 \%$ & $2,13 \%$ \\
\hline 3 & Balai Penelitian Tanaman Serealia & 9 & $9,28 \%$ & $1,90 \%$ \\
\hline 4 & Pusat Penelitian Kopi dan Kakao & 6 & $6,19 \%$ & $1,28 \%$ \\
\hline 5 & Lembaga Ilmu Pengetahuan Indonesia & 5 & $5,15 \%$ & $1,06 \%$ \\
\hline 6 & Balai Penelitian Tanaman Pemanis dan Serat & 4 & $4,12 \%$ & $0,85 \%$ \\
\hline 7 & Balai Penelitian Tanaman Sayuran & 3 & $3,10 \%$ & $0,64 \%$ \\
\hline 8 & Balai Penelitian Tanaman Tembakau dan Serat & 3 & $3,10 \%$ & $0,64 \%$ \\
\hline 9 & Balai Penelitian Tanaman Hias & 2 & $2,06 \%$ & $0,43 \%$ \\
\hline 10 & Perum Perhutani & 2 & $2,06 \%$ & $0,43 \%$ \\
\hline 11 & PT. Perkebunan Nusantara XI (Persero) & 2 & $2,06 \%$ & $0,43 \%$ \\
\hline 12 & Pusat Penelitian Tanaman Karet & 2 & $2,06 \%$ & $0,43 \%$ \\
\hline 13 & Badan Tenaga Nuklir Nasional & 1 & $1,03 \%$ & $0,21 \%$ \\
\hline 14 & Balai Penelitian Tanaman Aneka Kacang dan Umbi & 1 & $1,03 \%$ & $0,21 \%$ \\
\hline & Total & 97 & $100,00 \%$ & $20,64 \%$ \\
\hline
\end{tabular}

Sumber: Data Diolah dari Pusat PVTPP (2020)

Tabel 5. Perguruan Tinggi sebagai Pemulia Tanaman Pemegang Hak PVT hingga Tahun 2019

\begin{tabular}{c|l|c|c|c}
\hline \hline \multirow{2}{*}{ No } & \multicolumn{1}{|c|}{ Nama Pemegang Hak PVT } & \multicolumn{2}{|c|}{ Jumlah Hak PVT } & \multirow{2}{*}{$\begin{array}{c}\text { Presentase } \\
\text { Keseluruhan }\end{array}$} \\
\cline { 3 - 5 } & & Frekuensi & Presentase & $1,50 \%$ \\
\hline \hline 1 & Fakultas Pertanian, Universitas Padjadjaran & 7 & $46,66 \%$ & $0,64 \%$ \\
\hline 2 & Universitas Jenderal Soedirman & 3 & $19,99 \%$ & $0,21 \%$ \\
\hline 3 & $\begin{array}{l}\text { Direktorat Riset, Pengabdian pada Masyarakat dan } \\
\text { Inovasi, Universitas Padjadjaran }\end{array}$ & 1 & $6,67 \%$ & $0,21 \%$ \\
\hline 4 & Fakultas Pertanian, Universitas Jenderal Soedirman & 1 & $6,67 \%$ & $0,21 \%$ \\
\hline 5 & $\begin{array}{l}\text { Pusat Penelitian Sumber daya Hayati dan } \\
\text { Bioteknologi, Institut Pertanian Bogor }\end{array}$ & 1 & $6,67 \%$ & $0,21 \%$ \\
\hline 7 & Universitas Bengkulu & 1 & $6,67 \%$ & $0,21 \%$ \\
\hline \hline
\end{tabular}

Sumber: Data Diolah dari Pusat PVTPP (2020) 


\section{Tabel 6. Perusahaan Dalam Negeri sebagai Pemulia Tanaman Pemegang Hak PVT hingga Tahun 2019}

\begin{tabular}{|c|c|c|c|c|}
\hline \multirow{2}{*}{ No } & \multirow{2}{*}{ Nama Pemegang Hak PVT } & \multicolumn{2}{|c|}{ Jumlah Hak PVT } & \multirow{2}{*}{$\begin{array}{c}\text { Presentase } \\
\text { Keseluruhan }\end{array}$} \\
\hline & & Frekuensi & Presentase & \\
\hline 1 & PT. BISI International Tbk. & 108 & $37,76 \%$ & $22,99 \%$ \\
\hline 2 & PT. Agri Makmur Pertiwi & 79 & $27,62 \%$ & $16,81 \%$ \\
\hline 3 & PT. East West Seed Indonesia & 30 & $10,49 \%$ & $6,39 \%$ \\
\hline 4 & PT. Benih Citra Asia & 27 & $9,43 \%$ & $5,74 \%$ \\
\hline 5 & CV. Aura Seed Indonesia & 8 & $2,80 \%$ & $1,70 \%$ \\
\hline 6 & PT. Binasawit Makmur & 6 & $2,10 \%$ & $1,28 \%$ \\
\hline 7 & PT. Toba Pulp Lestari Tbk. & 6 & $2,10 \%$ & $1,28 \%$ \\
\hline 8 & PT. Jagung Hibrida Sulawesi & 5 & $1,75 \%$ & $1,06 \%$ \\
\hline 9 & PT. Nusantara Tropical Farm & 5 & $1,75 \%$ & $1,06 \%$ \\
\hline 10 & PT. Dupont Indonesia & 4 & $1,40 \%$ & $0,85 \%$ \\
\hline 11 & PT. Great Giant Pineapple & 4 & $1,40 \%$ & $0,85 \%$ \\
\hline 12 & PT. Arara Abadi & 1 & $0,35 \%$ & $0,21 \%$ \\
\hline 13 & PT. Bumi Mekar Tani & 1 & $0,35 \%$ & $0,21 \%$ \\
\hline 14 & PT. Primasid Andalan Utama & 1 & $0,35 \%$ & $0,21 \%$ \\
\hline 15 & PT. Socfin Indonesia dan PalmElit SAS & 1 & $0,35 \%$ & $0,21 \%$ \\
\hline & Total & 286 & $100,00 \%$ & $60,85 \%$ \\
\hline
\end{tabular}

Sumber: Data Diolah dari Pusat PVTPP (2020)

Tabel 7. Perusahaan Luar Negeri sebagai Pemulia Tanaman Pemegang Hak PVT hingga Tahun 2019

\begin{tabular}{c|c|c|c|c}
\hline \hline \multirow{2}{*}{ No Nama Pemegang Hak PVT } & \multicolumn{2}{|c|}{$\begin{array}{c}\text { Pumlah Hak PVT } \\
\text { Keseluruhase }\end{array}$} \\
\cline { 3 - 4 } & & Frekuensi & Presentase & 1,70\% \\
\hline \hline 1 & Monsanto Technology, LLC. & 8 & $20,00 \%$ & $1,28 \%$ \\
\hline 2 & Sichuan Guohao Seed Industry Co. Ltd. & 6 & $15,00 \%$ & $1,06 \%$ \\
\hline 3 & Bioseed Holdings PTE. LTD. & 5 & $12,50 \%$ & $0,85 \%$ \\
\hline 4 & SL. Agritech Corp & 4 & $10,00 \%$ & $0,85 \%$ \\
\hline 5 & Toyota Jidosha Kabushiki Kaisha & 4 & $10,00 \%$ & $0,64 \%$ \\
\hline 6 & Seed Asia Co. Ltd. Thailand & 3 & $7,50 \%$ & $0,64 \%$ \\
\hline 7 & Zespri Group Ltd. & 2 & $5,00 \%$ & $0,43 \%$ \\
\hline 8 & Better3fruit N.V. & 2 & $5,00 \%$ & $0,43 \%$ \\
\hline 9 & Dole Food Company, Inc. & 1 & $2,50 \%$ & $0,21 \%$ \\
\hline 10 & Bayer CropScience AG & $\mathbf{4 0}$ & $\mathbf{1 0 0 , 0 0 \%}$ & $\mathbf{8 , 5 1 \%}$ \\
\hline 11 & HZP Holland BV dan K. Dijkstra \& T. Dijkstra-Kooistra & 1 & $2,50 \%$ & $0,21 \%$ \\
\hline 12 & Pure Circle SDN BHD & 1 & $2,50 \%$ & $0,21 \%$ \\
\hline \hline
\end{tabular}

Sumber: Data Diolah dari Pusat PVTPP (2020) 
Tabel 8. Pemegang Hak PVT hingga Tahun 2019

\begin{tabular}{c|l|c|c}
\hline \hline \multirow{2}{*}{ No Status Pemegang Hak PVT } & \multicolumn{2}{c}{ Jumlah Hak PVT } \\
\cline { 3 - 4 } & \multicolumn{1}{|c|}{} & Frekuensi & Presentase \\
\hline \hline 1 & Perseorangan & 32 & $6,81 \%$ \\
\hline 2 & Pemerintah & 97 & $20,64 \%$ \\
\hline 3 & Perguruan Tinggi & 15 & $3,19 \%$ \\
\hline 4 & Perusahaan Dalam Negeri & 286 & $60,85 \%$ \\
\hline 5 & Perusahaan Luar Negeri & 40 & $8,51 \%$ \\
\hline \hline \multicolumn{2}{r}{ Total } & $\mathbf{4 7 0}$ & $\mathbf{1 0 0 , 0 0 \%}$ \\
\hline \hline
\end{tabular}

Sumber: Data Diolah dari Pusat PVTPP (2020)

Dari tabel di atas menunjukkan bahwa terdapat 32 atau 6,81\% yang berstatus perseorangan sebagai pemegang Hak PVT, terdapat 97 atau 20,64\% yang berstatus Pemerintah, terdapat 15 atau 3,19\% yang berstatus Perguruan Tinggi, terdapat 286 atau 60,85\% yang berstatus Perusahaan Dalam Negeri, dan terdapat 40 atau 8,51\% yang berstatus Perusahaan Luar Negeri. Dapat dinilai bahwa hingga Tahun 2019, Perusahaan Dalam Negeri merupakan pemulia tanaman dengan pemegang terbanyak atas Sertifikat Hak PVT.

Selanjutnya, terdapat lebih dari seribu perusahaan benih yang berbadan hukum, namun masih sedikit dari perusahaan tersebut melakukan aktifitas pemuliaan tanaman (Ahmad M. Ridwan, 2018). Kondisi ini disebabkan karena pada umumnya perusahaan tersebut tidak memiliki divisi penelitian dan pengembangan (litbang) (Bambang Sayaka, Frans B. M. Dabukke, \& Sri Suharyono, 2020). Diharapkan perusahaan perbenihan untuk menghadirkan divisi litbang guna meningkatkan jumlah varietas/varietas unggul baru dengan berbagai komoditi yang lebih kompetitif (Valeriana Darwis, 2016).

\section{KESIMPULAN}

Berdasarkan pembahasan di atas, maka dapat disimpulkan bahwa masih banyak petani yang melakukan aktifitas dalam menghadirkan varietas baru namun tidak mengajukan perolehan Hak PVT. Selain itu, terdapat lebih dari seribu perusahaan benih yang berbadan hukum, namun masih sedikit dari perusahaan tersebut melakukan aktifitas pemuliaan tanaman. Adapun perkembangan PVT berdasarkan UU No. 29 Tahun 2000 ialah terdapat 32 atau 6,81\% yang berstatus perseorangan sebagai pemegang Hak PVT, terdapat 97 atau 20,64\% yang berstatus Pemerintah, terdapat 15 atau 3,19\% yang berstatus Perguruan Tinggi, terdapat 286 atau 60,85\% yang berstatus Perusahaan Dalam Negeri, dan terdapat 40 atau 8,51\% yang berstatus Perusahaan Luar Negeri. Dari dasar kesimpulan tersebut, diharapkan peningkatan peran dari Pusat PVTPP dalam menjalankan kegiatan rutin juga memaksimalkan hubungan kerjasama bilateral dan regional. Lebih lanjut, diharapkan pula bagi setiap perusahaan perbenihan untuk memiliki divisi litbang guna meningkatkan jumlah varietas/varietas unggul baru dengan berbagai komoditi yang lebih kompetitif. 


\section{REFERENSI}

A. J. P. van Wijk. (2002). Framework for the introduction of Plant Breeders' Rights. Dalam Countries with an Emerging Plant Variety Protection System. Naktuinbouw: Center for Genetic Resources.

Ahmad M. Ridwan. (2018). Perlindungan Pengetahuan Tradisional Terkait dengan Keanekaraaman Hayati di Indonesia. Pemuliaan Hukum, Universitas Islam Nusantara, 1(1), hlm. 97-124.

Aktris Nuryanti. (2015). Sumber Daya Genetik dan Pengetahuan Tradisional Terkait Sumber Daya Genetik untuk Kemakmuran. Masalah-Masalah Hukum, Universitas Diponegoro, 44(4), hlm. 405-414. doi: https://doi.org/10.14710/ mmh.44.4.2015.405-414

Bambang Sayaka, Frans B. M. Dabukke, \& Sri Suharyono. (2020). Membangun Kemandirian Industri Benih Padi Nasional. Jurnal Ekonomi Indonesia, Pengurus Pusat Ikatan Sarjana Ekonomi Indonesia, 9(3), hlm. 189-207.

Brian Kusuma. (2018). Perlindungan terhadap Varietas Tanaman sebagai Bagian Hak Kekayaan Intelektual Menurut Undang-Undang Nomor 29 Tahun 2000. Lex Privatum, Universitas Sam Ratulangi, 6(6), hlm. 130-136.

Dwi Afni Maileni. (2014). Aspek Hukum Perlindungan Varietas Tanaman Ditinjau dari Undang-Undang Nomor 29 Tahun 2000 tentang Perlindungan Varietas Tanaman. Jurnal Dimensi, Universitas Riau Kepulauan, 3(2), hlm. 1-13. doi: http://dx.doi. org/10.33373/dms.v3i2.83

Emi Indah Lestari, Kholis Raisah, \& Adya Paramita Prabandari. (2019). Perlindungan Hukum terhadap Varietas Tanaman dalam Memberikan Kepastian Hukum kepada Pemulia Tanaman. Notarius, Universitas Diponegoro, 12(2), hlm. 972-984.

Fernando Simanjuntak \& Etty Susilowati. (2013). Perlindungan Hukum pada Pemberian Lisensi bagi Pemulia Varietas Tanaman. Law Reform, Universitas Diponegoro, 9(1), hlm. 1-26. doi: https://doi.org/10.14710/lr.v9i1.12433

H. Hermanto, et al. (Eds.). (2019). PVTPedia: Informasi Lengkap Perlindungan Varietas Tanaman. Jakarta: Pusat Perlindungan Varietas Tanaman dan Perizinan Pertanian, Kementerian Pertanian RI.

Hasim Ashari, Ujang Sumarwan, \& K. Kirbrandoko. (2013). Kepuasan Pelaku Usaha terhadap Kualitas Layanan Perizinan Pupuk di Kementerian Pertanian. Jurnal Manajemen \& Agribisnis, Institut Pertanian Bogor, 10(3), hlm. 156-164.

Hendra Djaya. (2015). Perlindungan Hukum terhadap Akses dan Pemanfaatan Sumber Daya Genetik. Jurnal Cakrawala Hukum, Universitas Merdeka Malang, 6(2), hlm. 141-151.

Iis Turniasih \& Nia Kania Dewi. (2007). Peranan Sektor Agroindustri dalam Pembangunan Nasional. Jurnal Geografi GEA, Universitas Pendidikan Indonesia, 7(2), hlm. 1-8. doi: https://doi.org/10.17509/gea.v7i2.1723

Ira Puspita Sari Wahyuni. (2013). Upaya Perlindungan Hukum terhadap Hak-Hak Petani Pemulia Tanaman di Indonesia. Kumpulan Jurnal Mahasiswa Fakultas Hukum, Hukum Universitas Brawijaya, 1(2), hlm. 1-20. 
Moch. Najib Imanullah. (2013). Politik Hukum Ketahanan Pangan Nasional (Kajian Sinkronisasi Politik Hukum Undang-Undang Hak PVT dan Undang-Undang Pangan). Yustisia, Universitas Sebelas Maret, 2(1), hlm. 87-99.

Naufal Hidayat, Tengku Keizeirina Devi Azwa, \& Detania Sukarja. (2019). Perlindungan Hukum Hak Atas Kekayaan Intelektual terhadap Varietas Tanaman (Studi Kasus Varietas Tanaman Jambu Madu Hijau Kabupaten Langkat). Transparency, Universitas Sumatera Utara, 2(1), hlm. 1-25.

Nurul Qamar \& Farah Syah Rezah. (2020). Metode Penelitian Hukum: Doktrinal dan Non-Doktrinal. Makassar: CV. Social Politic Genius (SIGn).

O. K. Saidin. (2010). Aspek Hukum Hak Kekayaan Intelektual (Intellectual Property Rights). Jakarta: PT. Raja Grafindo Persada.

Peraturan Menteri Pertanian Republik Indonesia Nomor 121/PERMENTAN/ OT.140/11/2013 tentang Syarat dan Tata Cara Permohonan dan Pemberian Hak Perlindungan Varietas Tanaman. (Berita Negara Republik Indonesia Tahun 2013 Nomor 1407).

Prasetyo Hadi Purwandoko \& Moch. Najib Imanullah. (2013). Perlindungan Variets Tanaman sebagai Salah Satu Bentuk perlindungan Hak Ekonomi Para Pemulia Tanaman Menuju ketahanan Pangan Nasional. Yustisia, Universitas Sebelas Maret, 2(3), hlm. 83-96.

Pusat PVTPP. (2020, 23 Juni). Pemberian Hak PVT. Dalam Pusat Perlindungan Varietas Tanaman dan Perizinan Pertanian, Kementerian Pertanian Republik Indonesia. Diakses dari http://pvtpp.setjen.pertanian.go.id/cms2017/category/beritaresmi/pemberian-hak-pvt/, pada tanggal 22 Oktober 2020.

Putu Ayu Sriasih Wesna. (2020). Doha Declaration sebagai Perlindungan Masyarakat atas Akses Obat Esensial di Negara Berkembang Pasca Trips Agreement. Kertha Wicaksana: Sarana Komunikasi Dosen dan Mahasiswa, Universitas Warmadewa, 14(1), hlm. 56-62.

Roosganda Elizabeth. (2019). Revitalisasi Implementasi Pemberdayaan Kelembagaan Pertanian Berkesinambungan Mendukung Pencapaian Daya Saing Produk Olahan. Unes: Journal of Scientech Research, Universitas Ekasakti, 4(1), hlm. 52-68.

Said Sampara \& La Ode Husen. (2016). Metode Penelitian Hukum. Makassar: Kretakupa Print.

Simona Bustani. (2019). Budaya Hukum Masyarakat Berdampak Terjadinya Kriminalisasi Petani yang Memanfaatkan Benih Varietas Baru (Dalam Mewujudkan Ketahanan Pangan). Hukum Pidana dan Pembangunan Hukum, Universitas Trisakti, 1(2), hlm. 1-6.

Sri Umi Lestari, Reza Prakoso Dwi Julianto, \& Astri Sumiati. (2017). Peningkatan Kemandirian Petani Melalui Produksi Benih Jagung Mandiri. JAPI (Jurnal Akses Pengabdian Indonesia), Universitas Tribuwana Tunggadewi Malang, 9(3), hlm. 9-17. 
Tito Hardiyanto \& Cecep Pardani. (2017). Analisis Keunggulan Kompetitif Beberapa Tanaman Pangan Utama di Kabupaten Ciamis. Mimbar Agribisnis: Jurnal Pemikiran Masyarakat Ilmiah Berwawasan Agribisnis, Universitas Galuh, 3(1), hlm. 73-88. doi: http://dx.doi.org/10.25157/ma.v3i1.77

Undang-Undang Republik Indonesia Nomor 5 Tahun 1990 tentang Konservasi Sumber Daya Alam Hayati dan Ekosistemnya. (Lembaran Negara Republik Indonesia Tahun 1990 Nomor 49. Tambahan Lembaran Negara Republik Indonesia Nomor 3419).

Undang-Undang Republik Indonesia Nomor 12 Tahun 1992 tentang Sistem Budidaya Tanaman. (Lembaran Negara Republik Indonesia Tahun 1992 Nomor 46. Tambahan Lembaran Negara Republik Indonesia Nomor 3478).

Undang-Undang Republik Indonesia Nomor 16 Tahun 1992 tentang Karantina Hewan, Ikan, dan Tanaman. (Lembaran Negara Republik Indonesia Tahun 1992 Nomor 56. Tambahan Lembaran Negara Republik Indonesia Nomor 3482).

Undang-Undang Republik Indonesia Nomor 7 Tahun 1994 tentang Pengesahan Agreement Establishing the World Trade Organization (Persetujuan Pembentukan Organisasi Perdagangan Dunia). (Lembaran Negara Republik Indonesia Tahun 1994 Nomor 57. Tambahan Lembaran Negara Republik Indonesia Nomor 3564).

Undang-Undang Republik Indonesia Nomor 29 Tahun 2000 tentang Perlindungan Varietas Tanaman. (Lembaran Negara Republik Indonesia Tahun 2000 Nomor 241. Tambahan Lembaran Negara Republik Indonesia Nomor 4043).

United Nations Tahun 1947 tentang General Agreement on Tariffs and Trade. (Disahkan pada tanggal 30 Oktober 1947, di Jenewa).

Valeriana Darwis. (2016). Implementasi Legislasi Benih dalam Mensukseskan Swasembada Pangan. SEPA: Jurnal Sosial Ekonomi Pertanian dan Agribisnis, Universitas Sebelas Maret, 12(2), hlm. 133-145.

Vina Eka Aristya \& T. Taryono. (2019). Pemuliaan Tanaman Partisipatif untuk Meningkatkan Peran Varietas Padi Unggul dalam Mendukung Swasembada Pangan Nasional. Agrotechnology Innovation (Agrinova), Universitas Gadjah Mada, 2(1), hlm. 26-35.

World Trade Organization Tahun 1994 tentang Agreement on Trade-Related Aspects of Intellectual Property Rights. (Disahkan pada tanggal 15 April 1994, di Marrakesh).

Yuliana Diah Warsiki Susi Irianti. (2017). Perjanjian Benefit Sharing sebagai Upaya Perlindungan dan Pemanfaatan Varietas Tanaman. Rechtidee, Universitas Trunojoyo, 12(1), hlm. 1-26. doi: https://doi.org/10.21107/ri.v12i1.2855

\footnotetext{
I Riezka Eka Mayasari \& Nur Hidayani Alimuddin. (2020). Analisis Hukum Perkembangan

Perlindungan Varietas Tanaman di Indonesia. Sovereign: Jurnal Ilmiah Hukum, CV. Social '

I Politic Genius (SIGn), 2(4), hlm. 1-14. doi: https://doi.org/10.37276/sjih.v2i4.39

ᄂ _ _ _ _ _ _ _ _ _ _ _ _ _ _ _ _ _ _ _ _ _ _ _ _ _ _ _ _ _ _ _ _ _ _ _ .
} 